\title{
Ecological stoichiometry and biomass response of Agropyron michnoi Roshev. under simulated N deposition in a sandy grassland, China
}

\author{
JIN Xiaoming $^{1 *}$, YANG Xiaogang ${ }^{1}$, ZHOU Zhen ${ }^{1}$, ZHANG Yingqi $^{2}$, YU Liangbin ${ }^{3}$, \\ ZHANG Jinghua ${ }^{1}$, LIANG Runfang ${ }^{3}$ \\ ${ }^{1}$ Department of Life Science, Hulunbuir University, Hulunbuir 021008, China; \\ ${ }^{2}$ College of Environmental Science, Northeast Normal University, Changchun 130024, China; \\ ${ }^{3}$ Grassland Research Institute, Chinese Academy of Agricultural Sciences, Hohhot 010010, China
}

\begin{abstract}
Sandy grassland in northern China is a fragile ecosystem with poor soil fertility. Exploring how plant species regulate growth and nutrient absorption under the background of nitrogen $(\mathrm{N})$ deposition is crucial for the management of the sandy grassland ecosystem. We carried out a field experiment with six N levels in the Hulunbuir Sandy Land of China from 2014 to 2016 and explored the Agropyron michnoi Roshev. responses of both aboveground and belowground biomasses and carbon (C), $\mathrm{N}$ and phosphorus (P) concentrations in the plant tissues and soil. With increasing $\mathrm{N}$ addition, both aboveground and belowground biomasses and $\mathrm{C}, \mathrm{N}$ and $\mathrm{P}$ concentrations in the plant tissues increased and exhibited a single-peak curve. C:N and C:P ratios of the plant tissues first decreased but then increased, while the trend for N:P ratio was opposite. The peak values of aboveground biomass, belowground biomass and $\mathrm{C}$ concentration in the plant tissues occurred at the level of $20 \mathrm{~g} \mathrm{~N} /\left(\mathrm{m}^{2} \cdot \mathrm{a}\right)$, while those of $\mathrm{N}$ and $\mathrm{P}$ concentrations in the plant tissues occurred at the level of $15 \mathrm{~g} \mathrm{~N} /\left(\mathrm{m}^{2} \cdot \mathrm{a}\right)$. The maximum growth percentages of aboveground and belowground biomasses were $324.2 \%$ and $75.9 \%$, respectively, and the root to shoot ratio (RSR) decreased with the addition of N. N and P concentrations in the plant tissues were ranked in the order of leaves $>$ roots $>$ stems, while $\mathrm{C}$ concentration was ranked as roots $>$ leaves $>$ stems. The increase in $\mathrm{N}$ concentration in the plant tissues was the largest (from $34 \%$ to $162 \%$ ), followed by the increase in P (from 10\% to 33\%) and C (from 8\% to 24\%) concentrations. The aboveground biomass was positively and linearly correlated with leaf C, N and P, and soil C and $\mathrm{N}$ concentrations, while the belowground biomass was positively and linearly correlated with leaf $\mathrm{N}$ and soil $\mathrm{C}$ concentrations. These results showed that the accumulation of $\mathrm{N}$ and $\mathrm{P}$ in the leaves caused the increase in the aboveground biomass, while the accumulation of leaf $\mathrm{N}$ resulted in the increase in the belowground biomass. $\mathrm{N}$ deposition can alter the allocation of $\mathrm{C}, \mathrm{N}$ and $\mathrm{P}$ stoichiometry in the plant tissues and has a high potential for increasing plant biomass, which is conducive to the restoration of sandy grassland.
\end{abstract}

Keywords: biomass; nitrogen deposition; plant tissue; C, N and P stoichiometry; sandy grassland

Citation: JIN Xiaoming, YANG Xiaogang, ZHOU Zhen, ZHANG Yingqi, YU Liangbin, ZHANG Jinghua, LIANG Runfang. 2020. Ecological stoichiometry and biomass response of Agropyron michnoi Roshev. under simulated N deposition in a sandy grassland, China. Journal of Arid Land, 12(5): 741-751. https://doi.org/10.1007/s40333-020-0014-9

\section{Introduction}

Since the Industrial Revolution, the use of fossil fuels and agricultural fertilizers has led to a

\footnotetext{
*Corresponding author: JIN Xiaoming (E-mail: nmgjinxm@163.com)

Received 2020-01-02; revised 2020-05-15; accepted 2020-05-20

(C) Xinjiang Institute of Ecology and Geography, Chinese Academy of Sciences, Science Press and Springer-Verlag GmbH Germany, part of Springer Nature 2020
} 
dramatic increase in atmospheric nitrogen $(\mathrm{N})$ deposition, reaching two to seven times the preindustrial level in some developed countries (Galloway et al., 2004). In the last 30 years, the increase rate of $\mathrm{N}$ deposition has reached $0.041 \mathrm{~g} /\left(\mathrm{m}^{2} \cdot \mathrm{a}\right)$ in China (Liu et al., 2013), which now represents the area with the greatest $\mathrm{N}$ deposition rate worldwide. The increase in global atmospheric $\mathrm{N}$ deposition has a direct impact on the regional $\mathrm{N}$ cycle, the health of humans and ecosystems, the balance of greenhouse gases and the biodiversity (Clark and Tilman, 2008). Previous studies have shown that in the N-deficient ecosystem, increasing $\mathrm{N}$ inputs can promote plant growth and increase the primary productivity of the entire ecosystem, but long-term $\mathrm{N}$ inputs can reduce plant growth (Magill et al., 2000). However, in the N-saturated ecosystem, excessive $\mathrm{N}$ inputs can inhibit plant growth and even lead to the degradation of ecosystem (Song et al., 2017). In a sandy grassland ecosystem that is characterized by the low soil $\mathrm{N}$ availability and critical $\mathrm{N}$ deposition loads (Duan et al., 2002; Yahdjian et al., 2011), $\mathrm{N}$ deposition is the main pathway by which $\mathrm{N}$ is inputted and plays a positive role in the significant increase in plant productivity, which is conducive to vegetation restoration (Fenn et al., 2003; Huang et al., 2018). Many studies have shown that, under low-N conditions, the amount of photosynthetic products that are distributed to belowground plant parts will increase (Grechi et al., 2007). With the addition of exogenous $\mathrm{N}$, the aboveground biomass of grassland ecosystem significantly increases (Lee et al., 2010), whereas the belowground biomass decreases (Bai et al., 2001). Nevertheless, the biomass of plants that are adapted to the particular environment significantly increases and those plants become the dominant species in the community (Bai et al., 2010).

Carbon (C), $\mathrm{N}$ and phosphorus (P) are structural elements and the major nutrient elements that play an important role in maintaining the biogeochemical cycle and ensuring both nutrient cycle and energy flow within ecosystem (Elser et al., 2000, 2010). Many studies have investigated the $\mathrm{N}$ and $\mathrm{P}$ levels in plant leaves, and $\mathrm{N}: \mathrm{P}$ ratio was used to measure nutrient limitations for individual species and entire ecosystems (Güsewell, 2004; Zhu et al., 2016). According to the theory of dynamic balance, organisms are capable of controlling many of their own characteristics, including the maintenance of nutrient balance and $\mathrm{pH}$ stability, so that their internal environment is not dramatically altered with the changes in external environment; furthermore, the concentration of individual element in organisms can be maintained within relatively narrow ranges (Zhang et al., 2003). However, higher plants can continually alter the distribution of $\mathrm{C}, \mathrm{N}$ and $\mathrm{P}$ concentrations and their relative amounts $(\mathrm{N}: \mathrm{P}, \mathrm{C}: \mathrm{N}$ and $\mathrm{C}: \mathrm{P})$ in response to biotic and abiotic factors, such as soil nutrients, functional groups, growth rates and biomass accumulations (Elser et al., 2010; Wu et al., 2012). N:P ratio of the soil solution as a key environmental factor influences both plant biomass and leaf N:P ratio (Güsewell, 2004; Wu et al., 2012). In previous study, more attention has been paid to the nutrient dynamics and relationship between soil and plant leaves (Lee et al., 2010). However, how plant tissues regulate $\mathrm{C}, \mathrm{N}$ and $\mathrm{P}$ concentrations and their ratios in response to $\mathrm{N}$ deposition as well as their relationships with biomass in sandy grasslands are still unclear. Grassland as an important terrestrial ecosystem, its productivity accounts for approximately one-third of the total ecosystem (Hoekstra et al., 2005); furthermore, the grassland ecosystem has important ecological services (Wrage et al., 2011). However, for a long time, imbalanced utilization by humans has led to the large-scale degradation and desertification of grassland ecosystem. Currently, the area of grassland desertification in China accounts for $16.7 \%$ of the total land area, and ecological security in northern China is severely threatened. Agropyron michnoi Roshev. is a typical rhizomatous grass species that is highly adaptable in the sandy grassland. In recent years, A. michnoi has been used in the establishment of windbreaks and for sand fixation in China. In the present study, we conducted a field experiment with $A$. michnoi for 3 years under $\mathrm{N}$ addition and analyzed the plant biomass and $\mathrm{C}, \mathrm{N}$ and $\mathrm{P}$ stoichiometry of the plant tissues and soil. The objectives of the study were to determine the following questions: (1) how plant tissues and soil stoichiometry respond to $\mathrm{N}$ addition? (2) how the aboveground and belowground biomasses of plants vary in response to $\mathrm{N}$ addition? and (3) how are plant biomass and tissue stoichiometry related? 


\section{Materials and methods}

\subsection{Study area}

The sandy grassland research station (2001-2018) is located in the Hulunbuir Sandy Land in northern China $\left(49.05^{\circ}-49.25^{\circ} \mathrm{N}, 118.20^{\circ}-118.40^{\circ} \mathrm{E} ; 560-670 \mathrm{~m}\right.$ a.s.1.). This area has a typical continental climate. The mean annual precipitation ranges from 250 to $300 \mathrm{~mm}$, with more than $70 \%$ occurring from June to September. The mean annual evaporation is 4-6 times that of the precipitation. The annual sunshine duration is approximately $3150 \mathrm{~h}$, and the annual mean temperature is $-1{ }^{\circ} \mathrm{C}$. The major soil type is sandy soil. The fixed sandy grassland, which consists of soil covered by sand, has relatively low species richness and vegetation cover. The species composition is dominated by drought-tolerant plant species, i.e., A. michnoi, Leymus chinensis, Carex duriuscula and Melissitus ruthenius. Thymus vulgaris constitutes the perennial plant species. A. japonica, Setaria viridis, Salsola foliosa, Agriophyllum squarrosum and Agriophylluns arenarium constitutes the annual plant species. The vegetation coverage is less than $40 \%$. A. michnoi is the single dominant species in the community. There are no differences in topography, soil type, or spatial heterogeneity among the study area.

\subsection{Experimental design}

The field was divided into three blocks, each separated by a 2-m buffer zone. In each block, we selected 12 plots $(6 \mathrm{~m} \times 6 \mathrm{~m})$, each separated by a 1 -m buffer zone for different treatments. The $\mathrm{N}$ addition experiments were carried out from 2014 to 2016. The fertilizer was $\mathrm{NH}_{4} \mathrm{NO}_{3}$, of which $46 \%$ was pure $\mathrm{N}$. There were six $\mathrm{N}$ levels, i.e., 0 (control, CK), 5, 10, 15, 20 and $25 \mathrm{~g} \mathrm{~N} /\left(\mathrm{m}^{2} \cdot \mathrm{a}\right)$. These $\mathrm{N}$ levels were referenced from historical $\mathrm{N}$ deposition data in northern China (Ti and Yan, 2010; Zhu et al., 2016). Hereafter, they were named as N0, N5, N10, N15, N20 and N25 treatments. $\mathrm{N}$ fertilizer was applied four times during the first $10 \mathrm{~d}$ of May, June, July and August, with a quarter of the annual amount applied each time. The $\mathrm{NH}_{4} \mathrm{NO}_{3}$ solutions were sprayed onto the plants from the foliage down to the soil surface. The amount of water applied to the plants in the CK treatment was the same as the amount of solution applied to the plants in other treatments ( $3 \mathrm{~L} /$ (plot.month), which was equal to $0.08 \mathrm{~mm} / \mathrm{month}$ ). This value was much less than the average precipitation amount, which is $40 \mathrm{~mm}$ in May and up to $110 \mathrm{~mm}$ in July. Pests and weeds were controlled manually.

\subsection{Field sampling}

In late August 2016, plants were randomly chosen from each treatment with a sampling frame (50 $\mathrm{cm} \times 50 \mathrm{~cm} \times 30 \mathrm{~cm})$. The plants were harvested, and their aboveground and belowground biomasses were determined. The soil was randomly sampled with an auger at a depth of $0-10 \mathrm{~cm}$. The soil samples were mixed in triplicate for each treatment, and the composition was determined. In addition, thirty plants with fully connected aboveground and belowground organs were randomly chosen from each treatment, stored in an insulated can and immediately taken to the laboratory for further analysis.

\subsection{Methods of measurement}

The belowground organs (rhizomes and fibrous roots) rinsed with distilled water and the aboveground organs (green leaves and stems) were dried in an oven at respectively $75^{\circ} \mathrm{C}$ for $48 \mathrm{~h}$ and $65^{\circ} \mathrm{C}$ for $48 \mathrm{~h}$ to measure the organ biomasses.

The formula for root to shoot ratio (RSR) is as follows:

$\mathrm{RSR}=$ belowground biomass/aboveground biomass.

The total $\mathrm{C}$, total $\mathrm{N}$ and total $\mathrm{P}$ concentrations were analyzed after the samples were finely ground in a Wiley mill and passed through a 40-mesh sieve. Total C concentration was measured with the $\mathrm{K}_{2} \mathrm{MnO}_{4}$ volumetric method, and total $\mathrm{N}$ concentration the Kjeldahl method via an Alpkem autoanalyzer (Kjektec System 2300 Distilling Unit, Sweden). Total P concentration was determined colorimetrically at $700 \mathrm{~nm}$ after the material was reacted with a molybdenum-antimony solution. After air-dried, we separated soil samples into three groups to measure the total $\mathrm{C}$, total $\mathrm{N}$ and total $\mathrm{P}$ concentrations. 


\subsection{Statistical analysis}

The statistical analysis was performed in SPSS version 23.0 (SPSS Inc., Chicago, IL, USA). One-way ANOVA (analysis of variance) was performed to test the effects of $\mathrm{N}$ addition on the biomass, RSR, C:N:P stoichiometry of plant and soil. Linear regression analysis was used to determine the relationships between $\mathrm{C}: \mathrm{N}: \mathrm{P}$ stoichiometry of plant and biomass, between $\mathrm{C}: \mathrm{N}: \mathrm{P}$ stoichiometry of soil and biomass, and between $\mathrm{C}: \mathrm{N}: \mathrm{P}$ stoichiometry of soil and leaves. The data are presented as mean \pm standard error (SE; $n=3$ ).

\section{Results}

\subsection{Changes in plant biomass and RSR}

With increasing $\mathrm{N}$ addition, both aboveground and belowground biomasses of $A$. michnoi significantly increased, reflecting a single-peak curve, and the peak value occurred under the N20 treatment (Fig. 1a and b). RSR of the plants tended to decrease under low levels of $\mathrm{N}$ addition (from N0 to N15), but kept stable under high levels of N addition (from N15 to N25) (Fig. 1c). The highest percentages of increases in aboveground and belowground biomasses were $324.2 \%$ and $75.9 \%$, respectively, under the $\mathrm{N} 20$ treatment compared with the N0 treatment. RSR of $A$. michnoi varied from 2.6 to 8.2 under different $\mathrm{N}$ treatments.
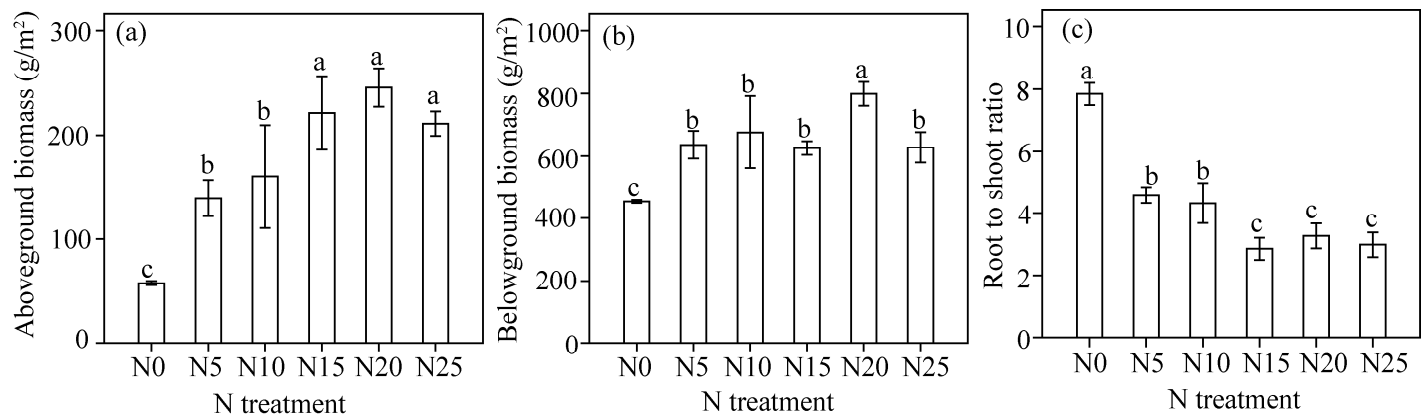

Fig. 1 Effects of $\mathrm{N}$ addition on plant biomass (a and b) and root to shoot ratio (c). N0, N5, N10, N15, N20 and $\mathrm{N} 25$ represent $0,5,10,15,20$ and $25 \mathrm{~g} \mathrm{~N} /\left(\mathrm{m}^{2} \cdot \mathrm{a}\right)$ additions, respectively. The abbreviations are the same in Figures 2 and 3. Bars indicate standard errors. Different lowercase letters above the bars indicate significant differences among different $\mathrm{N}$ treatments at $P<0.05$ level.

\subsection{Changes in $C, N$ and $P$ concentrations and $C: N: P$ ratios of plant}

$\mathrm{C}, \mathrm{N}$ and $\mathrm{P}$ concentrations in the roots, stems and leaves of A. michnoi significantly increased with $\mathrm{N}$ addition (Fig. 2a-c). With increasing $\mathrm{N}$ addition, the highest values were recorded under the N20 treatment for $\mathrm{C}$ concentration and under the N15 treatment for N and P concentrations. The increase in $\mathrm{N}$ concentration in the plant tissues was the largest (from $34 \%$ to $162 \%$ ), followed by the increase in P (from 10\% to $33 \%$ ) and $\mathrm{C}$ (from $8 \%$ to $24 \%$ ) concentrations. Under all the treatments, $\mathrm{N}$ and $\mathrm{P}$ concentrations in the plant tissues were ranked in the following order: leaves $>$ roots $>$ stems, while $\mathrm{C}$ concentration was ranked in the following order: roots $>$ leaves $>$ stems. With increasing $\mathrm{N}$ addition, $\mathrm{C}: \mathrm{N}$ ratios in the roots, stems and leaves, and $\mathrm{C}: \mathrm{P}$ ratio in the stems and leaves tended to initially decrease but then increase. However, $\mathrm{C}: \mathrm{P}$ ratio in the roots increased under high $\mathrm{N}$ treatments. N:P ratios in the roots, stems and leaves tended to initially increase but then decrease (Fig. 2d-f).

\subsection{Changes in $C, N$ and $P$ concentrations and $C: N$ :P ratios of soil}

With increasing $\mathrm{N}$ addition, soil total $\mathrm{C}$ concentration exhibited an increasing trend (Fig. 3). Soil total $\mathrm{N}$ and $\mathrm{P}$ concentrations significantly increased but then decreased, reflecting a single-peak curve, and all the highest values were recorded under the N15 treatment (Fig. 3a-c). Compared with soil $\mathrm{C}: \mathrm{N}$ ratio under the $\mathrm{N} 0$ treatment, soil $\mathrm{C}: \mathrm{N}$ ratios under the other treatments significantly decreased, and there were few differences among different $\mathrm{N}$ addition treatments (Fig. 3d). Soil $\mathrm{C}: \mathrm{P}$ and $\mathrm{N}: \mathrm{P}$ ratios initially increased but then decreased (Fig. $3 \mathrm{e}$ and $\mathrm{f}$ ). 

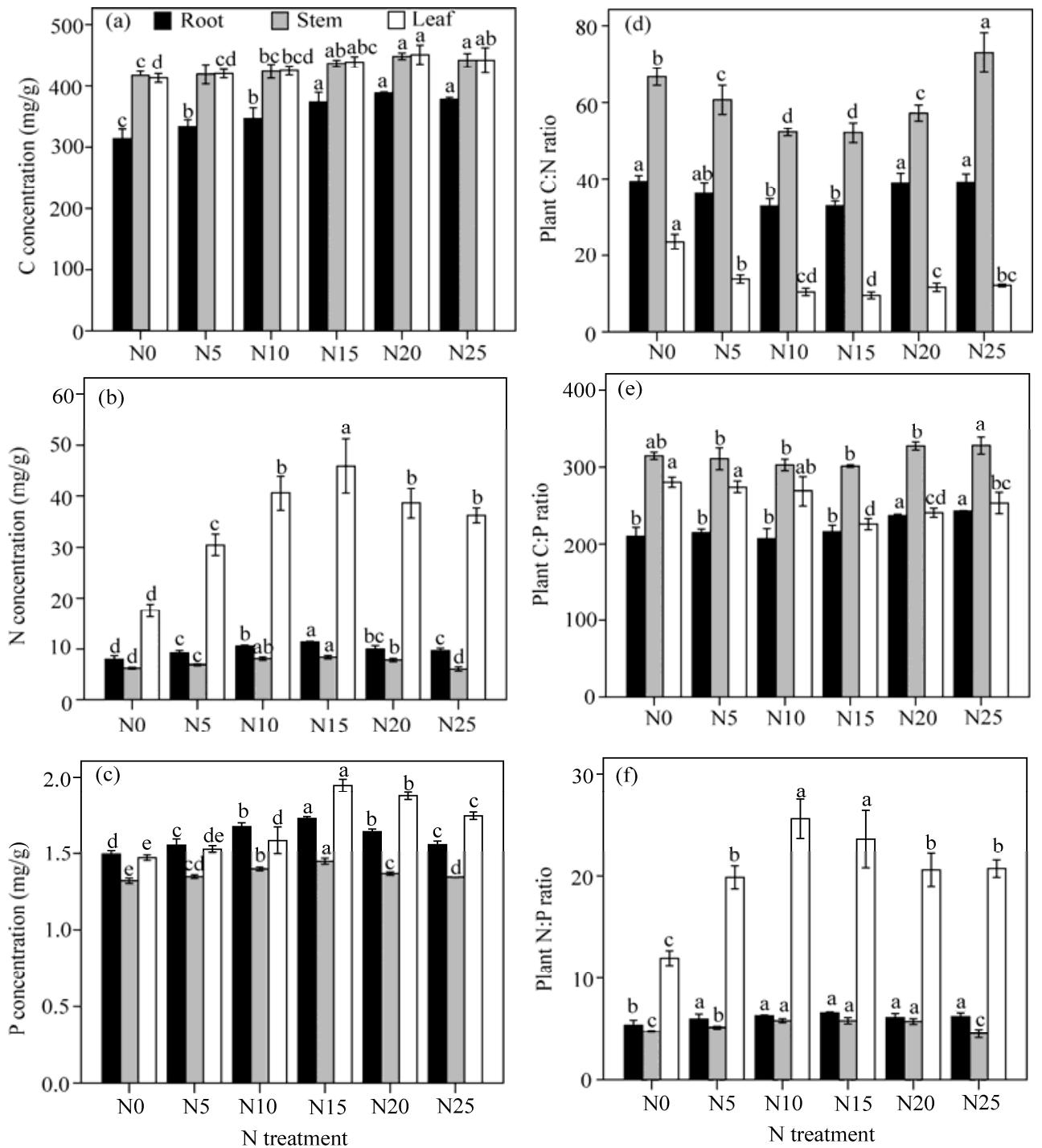

Fig. 2 Effects of $\mathrm{N}$ addition on $\mathrm{C}(\mathrm{a}), \mathrm{N}(\mathrm{b})$ and $\mathrm{P}(\mathrm{c})$ concentrations and $\mathrm{C}: \mathrm{N}(\mathrm{d}), \mathrm{C}: \mathrm{P}(\mathrm{e})$ and $\mathrm{N}: \mathrm{P}(\mathrm{f})$ ratios in the plant tissues. Bars indicate standard errors. Different lowercase letters above the bars represent significant differences among different $\mathrm{N}$ treatments within the same plant tissue at $P<0.05$ level.

\subsection{Relationships between plant biomass and $\mathrm{C}: \mathrm{N}: \mathrm{P}$ ratios of plant}

The relationships between plant biomass and C:N:P ratios of plant are shown in Figure 4. Positive linear relationships were found between the aboveground biomass and $\mathrm{C}$ concentrations in the leaves, stems and roots as well as $\mathrm{N}$ and $\mathrm{P}$ concentrations in the leaves (Fig. $4 \mathrm{a}-\mathrm{c}$ ). Among them, strong positive relationships were found between the aboveground biomass and $\mathrm{C}$ concentrations in the leaves and roots. In contrast, negative relationships were detected of the aboveground biomass with $\mathrm{C}: \mathrm{N}$ and $\mathrm{C}: \mathrm{P}$ ratios in the leaves (Fig. $4 \mathrm{~d}$ and e). However, positive linear relationship was only found between the belowground biomass and leaf $\mathrm{N}$ concentration (Fig. $4 \mathrm{~g}$ ).

\subsection{Relationships between plant biomass and $\mathrm{C}: \mathrm{N}: \mathrm{P}$ ratios of soil}

The relationships between plant biomass and C:N:P ratios of soil are shown in Figure 5. Positive linear relationships were detected of the aboveground and belowground biomasses of $A$. michnoi with soil $\mathrm{C}$ and $\mathrm{N}$ concentrations (Fig. 5a and b). In contrast, negative linear relationships were detected between the aboveground biomass and soil $\mathrm{C}: \mathrm{N}$ ratio and between the belowground biomass and soil $\mathrm{C}: \mathrm{N}$ ratio (Fig. $5 \mathrm{~d}$ ). 

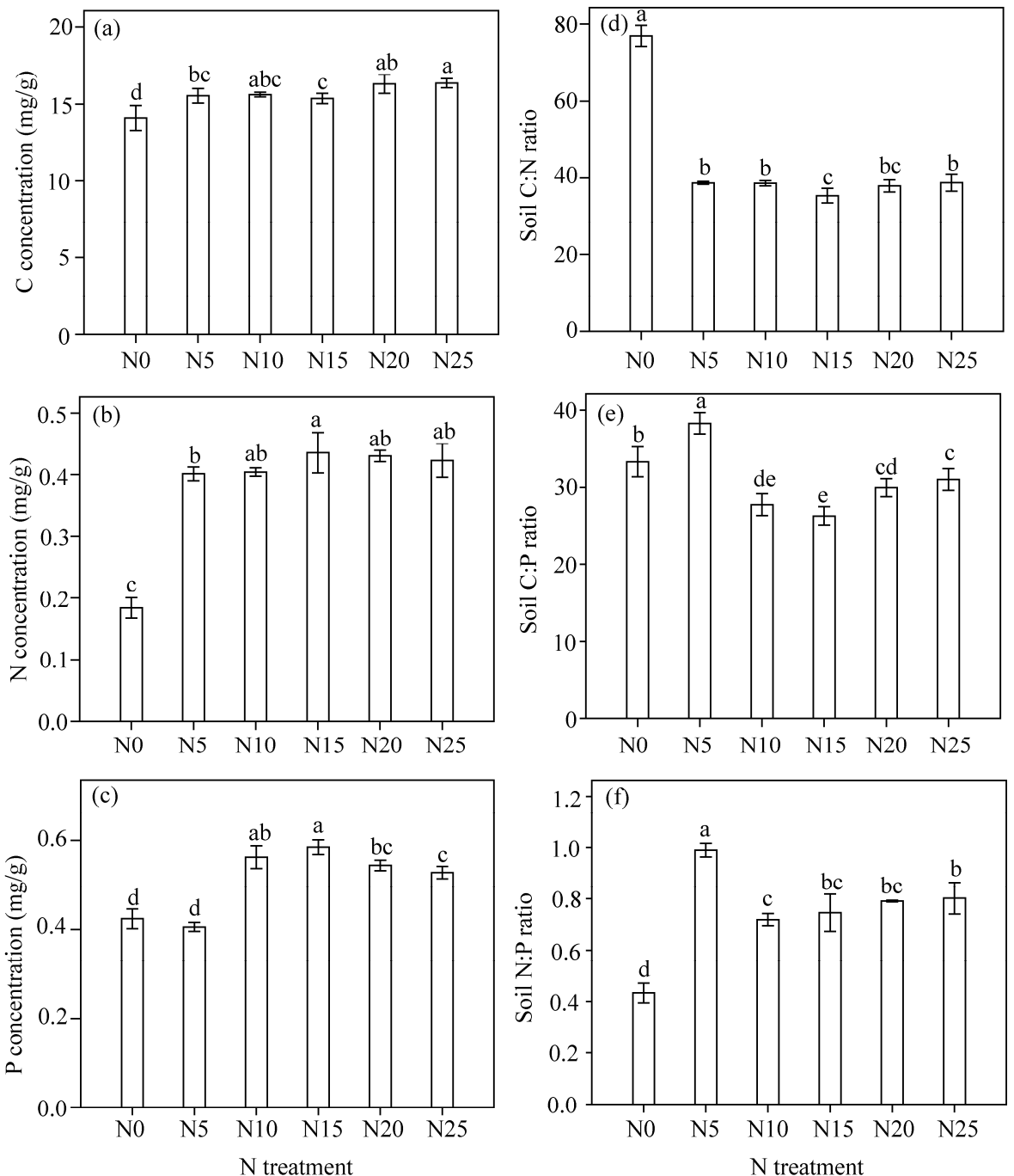

Fig. 3 Effects of $\mathrm{N}$ addition on $\mathrm{C}(\mathrm{a}), \mathrm{N}(\mathrm{b})$ and $\mathrm{P}(\mathrm{c})$ concentrations and C:N (d), C:P (e) and N:P (f) ratios of soil. Bars indicate standard errors. Different lowercase letters above the bars represent significant differences among different $\mathrm{N}$ treatments at $P<0.05$ level.

\subsection{Relationships among $\mathrm{C}: \mathrm{N}: \mathrm{P}$ ratios of plant and soil}

The relationships among $\mathrm{C}: \mathrm{N}: \mathrm{P}$ ratios of plant and soil are shown in Figure 6. A strong positive linear relationship was detected between the leaf $\mathrm{C}: \mathrm{N}$ ratio and soil $\mathrm{C}: \mathrm{N}$ ratio (Fig. 6a), and a positive linear relationship was detected between the leaf $\mathrm{N}: \mathrm{P}$ ratio and root N:P ratio (Fig. 6c).

\section{Discussion}

\subsection{Changes in plant biomass in response to $\mathbf{N}$ addition}

$\mathrm{N}$ and water are two important factors limiting the productivity of grassland ecosystem. In this ecosystem, $\mathrm{N}$ has different effects on plant photosynthesis and growth, leading to different plant productivity responses. In the dry environment, the migration and transmission of nutrients are limited. However, with an increase in precipitation, the nutrient limitations of the soil can be relieved, improving the nutrient availability, promoting the absorption and use of nutrients by plants, and ultimately, increasing ecosystem productivity (Li et al., 2013). Therefore, the interaction between $\mathrm{N}$ and water tends to be synergistic (Niu et al., 2009). 

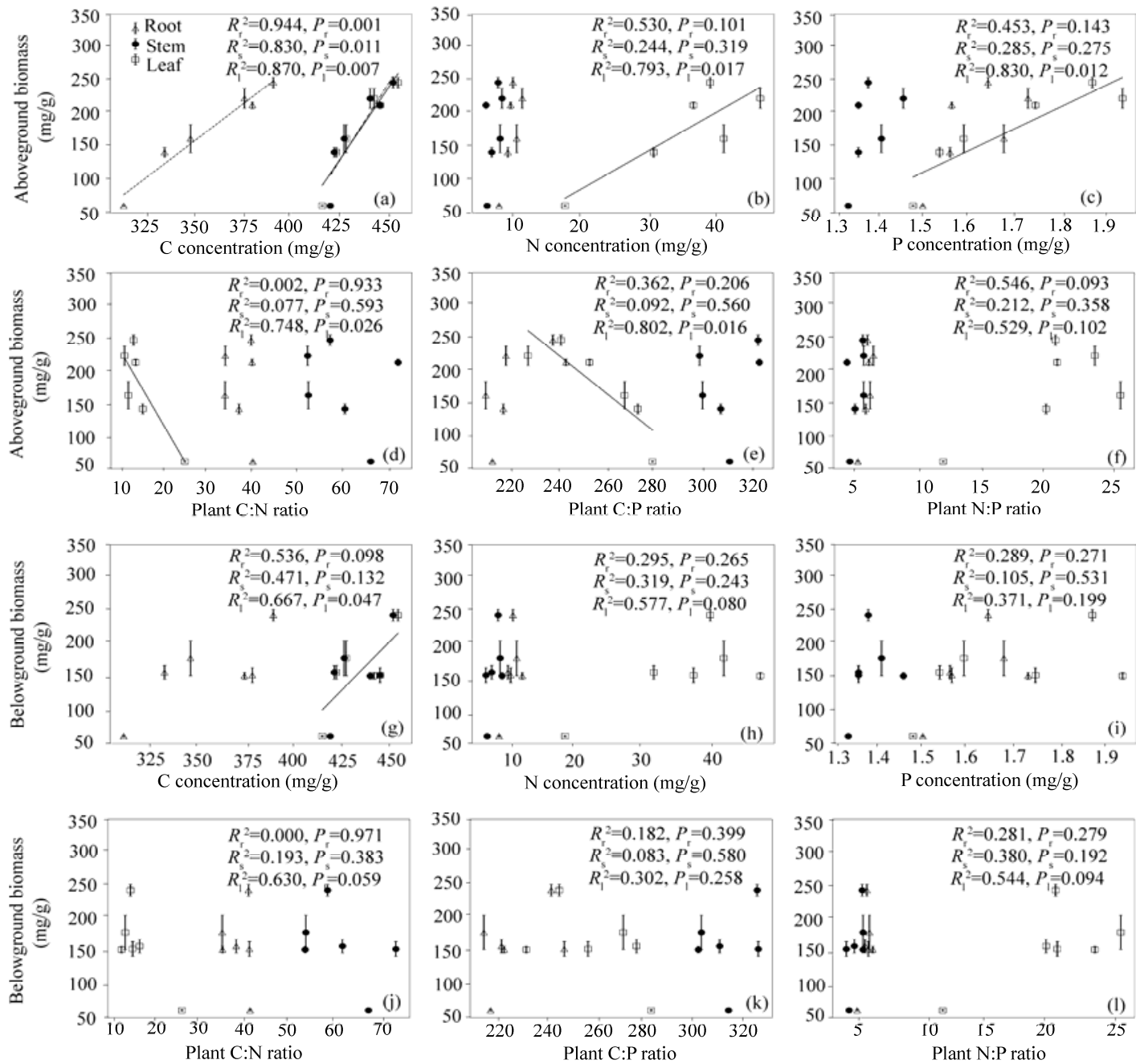

Fig. 4 Relationships of plant biomass with $\mathrm{C}$ (a and g), N (b and h) and P (c and i) concentrations and C:N (d and j), C:P (e and k) and N:P (f and l) ratios of plant. $R_{\mathrm{r}}{ }^{2}, R_{\mathrm{s}}{ }^{2}$ and $R_{1}{ }^{2}$ represent the coefficients of determination of root, stem and leaf of $A$. michnoi, respectively.
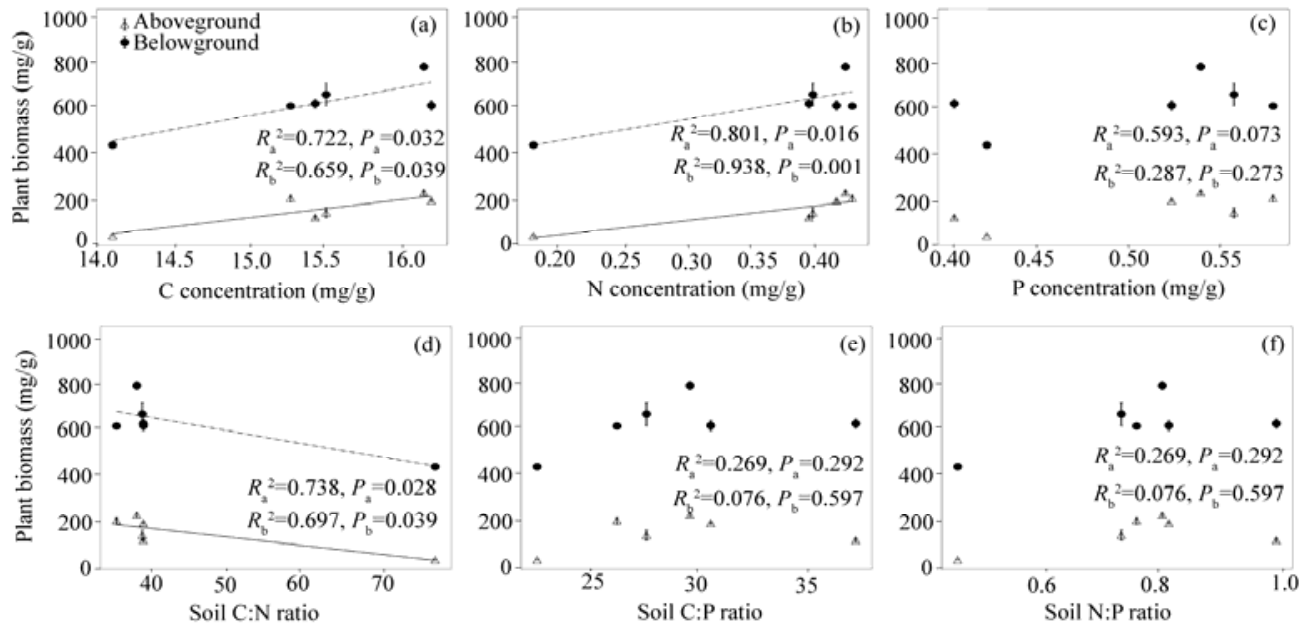

Fig. 5 Relationships of plant biomass with $\mathrm{C}(\mathrm{a}), \mathrm{N}(\mathrm{b})$ and $\mathrm{P}(\mathrm{c})$ concentrations and C:N (d), C:P (e) and N:P (f) ratios of soil. $R_{\mathrm{a}}{ }^{2}$ and $R_{\mathrm{b}}{ }^{2}$ represent the coefficients of determination of aboveground biomass and belowground biomass of $A$. michnoi, respectively. 


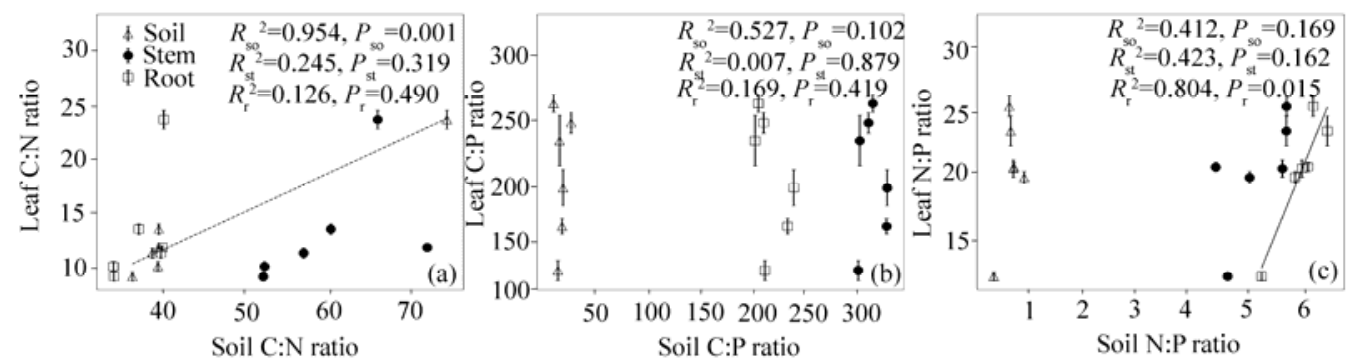

Fig. 6 Relationships among C:N (a), C:P (b) and N:P (c) ratios of leaf and soil. $R_{\mathrm{so}}{ }^{2}, R_{\mathrm{st}}{ }^{2}$ and $R_{\mathrm{r}}{ }^{2}$ represent the coefficients of determination of soil, stem and root of $A$. michnoi, respectively.

In the present study, with increasing $\mathrm{N}$ addition (the maximum of $20 \mathrm{~g} \mathrm{~N} /\left(\mathrm{m}^{2} \cdot \mathrm{a}\right)$ ), the aboveground and belowground biomasses tended to increase, but the plant biomass tended to decrease under high levels $\left(25 \mathrm{~g} \mathrm{~N} /\left(\mathrm{m}^{2} \cdot \mathrm{a}\right)\right)$ of $\mathrm{N}$ addition (Fig. 1a and $\left.\mathrm{b}\right)$. This finding indicated that an appropriate amount of added $\mathrm{N}$ was beneficial to the biomass accumulation of $A$. michnoi, but excessive $\mathrm{N}$ addition had no effect. These results are similar to those of other studies on $\mathrm{N}$ addition to grassland. $\mathrm{N}$ can improve plant growth within a certain range, but if the amount of $\mathrm{N}$ addition exceeds the minimum $\mathrm{N}$ saturation for plants in that region, the plants can be less sensitive to $\mathrm{N}$ deposition (Hedwall et al., 2013), and P limitation in grassland will increase, leading to a reduction in plant biomass (Menge and Field, 2007).

Studies have shown that plants can increase their allocation of photosynthetic products to belowground organs to obtain $\mathrm{N}$ under low $\mathrm{N}$ conditions (Grechi et al., 2007). Moreover, with increasing exogenous $\mathrm{N}$ addition, the aboveground biomass and productivity of a grassland community can significantly increase, leading to a reduction in RSR (Lee et al., 2010). In the present study, the belowground biomass was always greater than the aboveground biomass under $\mathrm{N}$ addition, while RSR decreased with increasing $\mathrm{N}$ addition. However, when the amount of $\mathrm{N}$ addition exceeded $15 \mathrm{~g} \mathrm{~N} /\left(\mathrm{m}^{2} \cdot \mathrm{a}\right)$, RSR tended to remain stable (Fig. 1c). It may be that clones of $A$. michnoi plants increase the allocation to the belowground components for facilitating resistance against harsh environmental conditions and expanding the population via vegetative propagation, thus leading to the maintenance of this species at the dominant position in the community (Jin et al., 2012).

\subsection{Linkage between plant biomass and $C: N: P$ ratios of plant}

Concentrations of $\mathrm{C}, \mathrm{N}$ and $\mathrm{P}$ in the plant leaves were detected to be $436.0,26.8$ and $1.8 \mathrm{~g} / \mathrm{kg}$, respectively, in Inner Mongolia, China (He et al., 2006). These values were greater than 413.0, 17.6 and $1.47 \mathrm{~g} / \mathrm{kg}$, respectively, in the current study, under no $\mathrm{N}$ addition (Fig. 2a-c). This is because plants that normally grow in the low-fertility soil have relatively low nutrient concentrations, while plant nutrient concentrations increase with increased soil nutrient concentrations (Xu et al., 2016). An analysis of the stoichiometric characteristics of plants in response to $\mathrm{N}$ addition in a Stipa baicalensis grassland in Inner Mongolia, China, revealed that the concentrations of leaf $\mathrm{C}$ and $\mathrm{N}$ in Gramineae plants increased in response to the $\mathrm{N}$ addition and that the concentration of leaf $P$ decreased (Liu et al., 2018). The same results were obtained in a study of Schima superba, in which increases in $\mathrm{N}$ availability in response to the $\mathrm{N}$ deposition were typically associated with the increases in $\mathrm{N}$ concentration and the decreases in $\mathrm{P}$ concentration (Zhang et al., 2018). In our study, concentrations of C, N and P in the roots, stems and leaves of $A$. michnoi significantly increased under different $\mathrm{N}$ treatments (Fig. 2a-c). These increases may have occurred because $\mathrm{N}$ addition may have increased the available $\mathrm{N}$ concentration in the soil during the plant growing season, increasing the absorption of $\mathrm{N}$ by plant roots (Liu et al., 2018). Moreover, an increase in $\mathrm{N}$ uptake results in an increased uptake of other nutrients, such as $\mathrm{P}$, which may become limiting over time ( $\mathrm{Lu}$ et al., 2018). However, $\mathrm{P}$ concentration in the leaves increased, possibly because, first, the plants themselves increased the expression of genes encoding acid phosphatase and other genes expressed outside epidermal cells to adapt to the low $\mathrm{P}$ stress, and the increased activity of acid phosphatase was beneficial for the decomposition of organic P in the soil (Liu et al., 2004). Second, the increase in P concentration may be due to the differences in grassland types and species. Third, P inputs may have increased with increasing belowground root biomass and plant litter (Zhou et al., 2015). 
In the present study, the aboveground biomass was positively related to $\mathrm{C}$ concentrations in the leaves, stems and roots as well as $\mathrm{N}$ and $\mathrm{P}$ concentrations in the leaves (Fig. $4 \mathrm{a}-\mathrm{c}$ ). Negative relationships were detected of the aboveground biomass with $\mathrm{C}: \mathrm{N}$ and $\mathrm{C}: \mathrm{P}$ ratios of the leaves (Fig. 4d and e). However, positive relationships were found only between the belowground biomass and leaf $\mathrm{N}$ concentration (Fig. 4g). These results indicated that the increases in the aboveground biomass in response to the $\mathrm{N}$ addition were dependent on the increases in both $\mathrm{N}$ and $\mathrm{P}$ concentrations of the leaves, while the increases in the belowground biomass were dependent only on the leaf $\mathrm{N}$ concentration.

According to the plant growth rate hypothesis, the relative growth rate and $\mathrm{C}: \mathrm{N}$ ratio were negatively correlated when $\mathrm{N}$ was limiting and positively when $\mathrm{P}$ was limiting. When $\mathrm{N}$ or $\mathrm{P}$ is no longer a limiting element, plants will absorb these elements in excess and store it, resulting in a reduction in the use efficiency of these elements (Ågren, 2004). In the previous study, the differences in nutrient storage and metabolic function make plant stems and roots less sensitive to environmental changes than plant leaves, and $\mathrm{N}$ addition has little to do with $\mathrm{C}: \mathrm{N}, \mathrm{C}: \mathrm{P}$ and $\mathrm{N}: \mathrm{P}$ ratios of the stems and roots. However, we detected significant changes in the $\mathrm{C}, \mathrm{N}$ and $\mathrm{P}$ concentrations and $\mathrm{C}: \mathrm{N}, \mathrm{C}: \mathrm{P}$ and $\mathrm{N}: \mathrm{P}$ ratios not only in the leaves but also in the roots and stems of A. michnoi. We also found that $\mathrm{C}, \mathrm{N}$ and $\mathrm{P}$ concentrations in the plant tissues increased, and these increases were reflected by a single-peak curve with increasing $\mathrm{N}$ addition (Figs. 2a-c), moreover, $\mathrm{C}: \mathrm{N}$ and $\mathrm{C}: \mathrm{P}$ ratios of the plant tissues first decreased but then increased, while the trend for $\mathrm{N}: \mathrm{P}$ ratio was the opposite (Fig. 2d-f). Furthermore, the aboveground biomass was negatively correlated with $\mathrm{C}: \mathrm{N}$ and $\mathrm{C}: \mathrm{P}$ ratios (Fig. $4 \mathrm{~d}$ and e). These results indicate that $A$. michnoi adapts to environmental changes by coordinating $\mathrm{C}, \mathrm{N}$ and $\mathrm{P}$ concentrations and $\mathrm{C}: \mathrm{N}, \mathrm{C}: \mathrm{P}$ and $\mathrm{N}: \mathrm{P}$ ratios in its roots, stems and leaves to achieve a high potential plant biomass in response to $\mathrm{N}$ deposition, which is conductive to the restoration of sandy grassland.

$\mathrm{N}: \mathrm{P}$ ratio of the plant leaves usually indicates $\mathrm{N}$ or P limitation. Plant growth was respectively limited by $\mathrm{N}, \mathrm{P}$ and both when the ratio was $<21,>23$ and $21-23$. With increasing $\mathrm{N}$ deposition, $\mathrm{N}$ limitation in degraded grasslands is alleviated, and leaf N:P ratio increases; however, owing to the long-term or excessive $\mathrm{N}$ deposition, $\mathrm{N}$ saturation can occur in these ecosystems, resulting in an imbalanced N:P ratio, which causes the limited P for plant growth (Wardle et al., 2013). Critical indices of $\mathrm{N}: \mathrm{P}$ ratio were proposed via $\mathrm{N}$ addition experiments with Leymus chinensis and Carex korshinskyi in a steppe ecosystem in Inner Mongolia Autonomous Region (Zhang et al., 2004). Our findings showed that the growth of $A$. michnoi was limited by $\mathrm{N}$ under low $\mathrm{N}$ addition (N0 and N5), limited by $\mathrm{P}$ under moderate $\mathrm{N}$ addition (N10 and N15) and limited by both $\mathrm{N}$ and $\mathrm{P}$ under high $\mathrm{N}$ addition ( 20 and N25). This is possibly because, with respect to soil fertility, the sandy grassland was poor in $\mathrm{N}$ and $\mathrm{P}$, especially $\mathrm{N}$. The $\mathrm{N}$ tended to be saturated with increasing $\mathrm{N}$ addition, and plant growth was limited by $\mathrm{P}$. In addition, plant biomass increased with increasing amounts of added $\mathrm{N}$, and plant requirements for $\mathrm{P}$ also increased, resulting in the limitations of both $\mathrm{N}$ and $\mathrm{P}$. It was also found that the greater positive response of the leaf $\mathrm{N}: \mathrm{P}$ ratio to $\mathrm{N}$ addition likely resulted in the greater root $\mathrm{N}: \mathrm{P}$ ratio of the plant (Fig. 6c). These results indicated that $A$. michnoi had the capacity to regulate $\mathrm{N}: \mathrm{P}$ ratios of the roots and leaves, which had been described in previous studies (Huang et al., 2018).

\subsection{Linkage between plant biomass and $C: N: P$ ratios of soil}

The distribution of soil nutrients was associated with such plant characteristics as nutrient stoichiometry, partitioning of aboveground and belowground biomasses, biomass cycling rate and rooting depth (Jobbágy and Jackson, 2001), especially soil C and N storages (Li et al., 2013). On the basis of an analysis of the characteristic of $C: N: P$ ratio of the $0-10 \mathrm{~cm}$ soil layer, $\mathrm{C}: \mathrm{N}$ and $\mathrm{N}: \mathrm{P}$ ratios of the surface soil could adequately indicate the supply status of soil N (Tian et al., 2010). Desert steppe ecosystem has relatively a low soil N:P ratio (Delgado-Baquerizo et al., 2013), and soil $\mathrm{N}: \mathrm{P}$ ratio can increase in response to $\mathrm{N}$ deposition in the long term and at large scales, gradually shifting the relationship between soil N and P (Vitousek et al., 2010). Soil C:N and C:P ratios have an important effect on plant growth (Wang and Yu, 2008; Yu et al., 2014). Our results showed that soil total $\mathrm{C}$, total $\mathrm{N}$ and $\mathrm{N}: \mathrm{P}$ ratio increased in response to $\mathrm{N}$ addition and that soil $\mathrm{C}: \mathrm{N}$ and $\mathrm{C}: \mathrm{P}$ ratios decreased (Fig. 3a, b, $\mathrm{d}$ and e). Moreover, positive relationships were detected of the aboveground and belowground biomasses with soil $\mathrm{N}$ and $\mathrm{C}$ concentrations, respectively, while negative relationships were detected of the aboveground and belowground biomasses with soil $\mathrm{C}: \mathrm{N}$ ratio (Fig. 5). These results indicated that $\mathrm{N}$ deposition alleviated plant $\mathrm{N}$ limitation, promoted plant growth and biomass accumulation, and increased soil total $\mathrm{C}$ concentration. 
Therefore, $\mathrm{N}$ deposition can effectively increase soil $\mathrm{C}$ and $\mathrm{N}$ storages and promote the restoration of sandy grassland.

\section{Conclusions}

The sandy grassland of northern China is a fragile ecosystem with poor soil fertility. Exploring how plants regulate growth and nutrient absorption under the background of $\mathrm{N}$ deposition is crucial for the management of sandy grassland ecosystem. We conducted an $\mathrm{N}$ supply field experiment with A. michnoi in the Hulunbuir Sandy Land of China. With increasing N addition, aboveground and belowground biomasses, and $\mathrm{C}, \mathrm{N}$ and $\mathrm{P}$ concentrations in the plant tissues increased, and these increases were reflective of a single-peak curve. The aboveground biomass accumulated faster than the belowground biomass, $\mathrm{N}$ accumulated faster than $\mathrm{P}$ in the plant tissues, and $\mathrm{C}$ accumulated relatively slowly. The aboveground biomass was positively and linearly correlated with leaf $\mathrm{C}, \mathrm{N}$ and $\mathrm{P}$ concentrations, and soil $\mathrm{C}$ and $\mathrm{N}$ concentrations, while the belowground biomass was positively and linearly correlated with root $\mathrm{N}$ and soil $\mathrm{C}$ concentrations. The results showed that the accumulations of $\mathrm{N}$ and $\mathrm{P}$ in the leaves played a major role in the increase of the aboveground biomass, while the accumulation of root $\mathrm{N}$ played a major role in the increase of the belowground biomass. $\mathrm{N}$ deposition can alter the allocation of $\mathrm{C}, \mathrm{N}$ and $\mathrm{P}$ stoichiometry in the plant tissues and has a high potential for increasing plant biomass, which is conducive to the restoration of sandy grasslands. However, the present study was performed for only three years in the field and the simulated results needs to be comprehensively confirmed in other sandy grasslands where the vertical distribution of soil nutrients is dominated by plant cycling.

\section{Acknowledgements}

This study was funded by the National Natural Science Foundation of China (31560657) and the Natural Science Foundation of Inner Mongolia Autonomous Region, China (2018MS03079). We gratefully acknowledge the help of students, technicians and field workers in the field investigation.

\section{References}

Ågren G I. 2004. The C:N:P stoichiometry of autotrophs-theory and observations. Ecology Letters, 7(3): $185-191$.

Bai Y F, Wu J G, Clark C M, et al. 2010. Tradeoffs and thresholds in the effects of nitrogen addition on biodiversity and ecosystem functioning: evidence from Inner Mongolia grasslands. Global Change Biology, 16(1): 358-372.

Bai Y F, Li L H, Huang J H, et al. 2001. Exacerbated nitrogen limitation ends transient stimulation of grassland productivity by increased precipitation. Acta Botanica Sinica, 43: 280-287. (in Chinese)

Clark C M, Tilman D. 2008. Loss of plant species after chronic low-level nitrogen deposition to prairie grasslands. Nature, 451 : $712-715$.

Delgado-Baquerizo M, Maestre F T, Gallardo A, et al. 2013. Decoupling of soil nutrient cycles as a function of aridity in global drylands. Nature, 502: 672-676.

Duan L, Hao J M, Xie S D, et al. 2002. Estimating critical loads of sulfur and nitrogen for Chinese soils by steady state method. Environmental Science, 23(2): 7-12. (in Chinese)

Elser J J, Fagan W F, Denno R F, et al. 2000. Nutritional constraints in terrestrial and freshwater food webs. Nature, 408: $578-580$.

Elser J J, Acharya K, Kyle M, et al. 2010. Growth rate-stoichiometry couplings in diverse biota. Ecology Letters, 6(10): 936-943.

Fenn M E, Baron J S, Allen E B, et al. 2003. Ecological effects of nitrogen deposition in the western United States. BioScience, 53(4): 404-420.

Galloway J N, Dentener F J, Capone D G, et al. 2004. Nitrogen cycles: past, present, and future. Biogeochemistry, 70: 153-226.

Grechi I, Vivin P, Hilbert G, et al. 2007. Effect of light and nitrogen supply on internal C:N balance and control of root-to-shoot biomass allocation in grapevine. Environmental and Experimental Botany, 59(2): 139-149.

Güsewell S. 2004. N: P ratios in terrestrial plants: variation and functional significance. New Phytologist, 164(2): $243-266$.

He J S, Fang J, Wang Z, et al. 2006. Stoichiometry and large-scale patterns of leaf carbon and nitrogen in the grassland biomes of China. Oecologia, 149: 115-122.

Hedwall P O, Nordin A, Strengbom J, et al. 2013. Does background nitrogen deposition affect the response of boreal vegetation to fertilization? Oecologia, 173: 615-624.

Hoekstra J M, Boucher T M, Ricketts T H, et al. 2005. Confronting a biome crisis: global disparities of habitat loss and 
protection. Ecology Letters, 8(1): 23-29.

Huang J Y, Yu H L, Liu J L, et al. 2018. Phosphorus addition changes belowground biomass and C:N:P stoichiometry of two desert steppe plants under simulated N deposition. Scientific Reports, 8: 3400.

Jin X M, Liu J D, Lu X S, et al. 2012. Relationship between vegetateve potential population and actual population of Agropyron michnoi. Acta Prataculturae Sinica, 21(6): 234-240. (in Chinese)

Jobbágy E G, Jackson R B. 2001. The distribution of soil nutrients with depth: global patterns and the imprint of plants. Biogeochemistry, 53: 51-77.

Lee M, Manning P, Rist J, et al. 2010. A global comparison of grassland biomass responses to $\mathrm{CO}_{2}$ and nitrogen enrichment. Philosophical Transactions of the Royal Society B: Biological Sciences, 365(1549): 2047-2056.

Li M M, Zhang X C, Pang G W, et al. 2013. The estimation of soil organic carbon distribution and storage in a small catchment area of the loess plateau. Catena, 101: 11-16.

Liu H M, Li J, Wang L L, et al. 2018. Effects of nitrogen addition on the stoichiometric characteristics of plants and soil in the Stipa baicalensis grassland of Inner Mongolia, China. Acta Prataculturae Sinica, 27(7): 25-35. (in Chinese)

Liu X J, Zhang Y, Han W X, et al. 2013. Enhanced nitrogen deposition over China. Nature, 494: 459-462.

Liu Y, Mi G H, Chen F J, et al. 2004. Rhizosphere effect and root growth of two maize (Zea mays L.) genotypes with contrasting P efficiency at low P availability. Plant Science, 167(2): 217-223.

Lu X H, Vitousek P M, Mao Q G, et al. 2018. Plant acclimation to long-term high nitrogen deposition in an N-rich tropical forest. Proceedings of the National Academy of Sciences of of the United States of America, 115(20): 5187-5192.

Magill A H, Aber J D, Berntson G M, et al. 2000. Long-term nitrogen additions and nitrogen saturation in two temperate forests. Ecosystems, 3: 238-253.

Menge D N L, Field C B. 2007. Simulated global changes alter phosphorus demand in annual grassland. Globle Change Biology, 13(12): 2582-2591.

Niu S L, Yang H J, Zhang Z, et al. 2009. Non-additive effects of water and nitrogen addition on ecosystem carbon exchange in a temperate steppe. Ecosystems, 12: 915-926.

Song X Z, Li Q, Gu H H. 2017. Effect of nitrogen deposition and management practices on fine root decomposition in moso bamboo plantations. Plant and Soil, 410: 207-215.

Ti C P, Yan X Y. 2010. Estimation of atmospheric nitrogen wet deposition in China's mainland from based on $\mathrm{N}$ emission data. Journal of Agro-Environment Science, 29: 1606-1611. (in Chinese)

Tian H Q, Chen G S, Zhang C, et al. 2010. Pattern and variation of C:N:P ratios in China's soils: a synthesis of observational data. Biogeochemistry, 98: 139-151.

Vitousek P M, Porder S, Houlton B Z, et al. 2010. Terrestrial phosphorus limitation: mechanisms, implications, and nitrogen-phosphorus interactions. Ecological Application, 20(1): 5-15.

Wang S Q, Yu G R. 2008. Ecological stoichiometry characteristics of ecosystem carbon, nitrogen and phosphorus elements. Acta Ecologica Sinica, 28(8): 3937-3947. (in Chinese)

Wardle D A, Gundale M J, Jäderlund A, et al. 2013. Decoupled long-term effects of nutrient enrichment on aboveground and belowground properties in subalpine tundra. Ecology, 94(4): 904-919.

Wrage N, Strodthoff J, Cuchillo H M, et al. 2011. Phytodiversity of temperate permanent grasslands: ecosystem services for agriculture and livestock management for diversity conservation. Biodiversity and Conservation, 20: 3317-3339.

Wu T G, Yu M K, Wang G, et al. 2012. Leaf nitrogen and phosphorus stoichiometry across forty-two woody species in Southeast China. Biochemical Systematics and Ecology, 44: 255-263.

Xu B C, Gao Z J, Wang J, et al. 2016. N:P ratio of the grass Bothriochloa ischaemum mixed with the legume Lespedeza davurica under varying water and fertilizer supplies. Plant and Soil, 400: 67-79.

Yahdjian L, Gherardi L, Sala O E. 2011. Nitrogen limitation in arid-subhumid ecosystems: a meta-analysis of fertilization studies. Journal of Arid Environments, 75(8): 675-680.

Yu Y F, Peng W X, Song T Q, et al. 2014. Stoichiometric characteristics of plant and soil C, N and P in different forest types in depressions between Karst hills, Southwest China. Chinese Journal of Applied Ecology, 25(4): 947-954. (in Chinese)

Zhang L X, Bai Y F, Han X G. 2003. Application of N:P stoichiometry to ecology studies. Acta Botanica Sinica, 45: $1009-1018$. (in Chinese)

Zhang L X, Bai Y F, Han X G. 2004. Differential responses of N:P stoichiometry of Leymus chinensis and Carex korshinskyi to $\mathrm{N}$ additions in a steppe ecosystem in Nei Mongol. Acta Botanica Sinica, 46(2): 259-270. (in Chinese)

Zhang R, Pan H W, He B T, et al. 2018. Nitrogen and phosphorus stoichiometry of Schima superba under nitrogen deposition. Scientific Reports, 8: 13669.

Zhou Z H, Wang C K, Zhang Q Z. 2015. The effect of land use change on soil carbon, nitrogen, phosphorus contents and their stoichiometry in temperate sapling stands in Northeastern China. Acta Ecologica Sinica, 35(20): 6694-6702. (in Chinese)

Zhu J X, Wang Q F, He N P, et al. 2016. Imbalanced atmospheric nitrogen and phosphorus depositions in China: implications for nutrient limitation. Journal of Geophysical Research-Biogeoscience, 121(6): 1605-1616. 